\title{
ESTIMASI ZONA POTENSIAL PENANGKAPAN IKAN (ZPPI) PROVINSI BENGKULU MENGGUNAKAN CITRA SATELIT MODIS AQUA
}

\author{
Rina Julita ${ }^{\mathrm{a}}$, Mujiono* ${ }^{\mathrm{b}}$

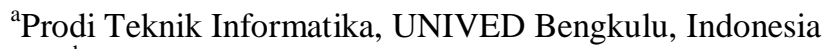 \\ ${ }^{\mathrm{b}}$ Prodi Agribisnis, UNIVED Bengkulu, Indonesia \\ *Koresponden penulis : mujiono@unived.ac.id
}

\begin{abstract}
Abstrak
Penelitian bertujuan untuk; (1) mengetahui paramater tradisional masyarakat provinsi Bengkulu dalam menentukan zona tangkap ikan, (2) memetakan zona potensial penangkapan ikan (ZPPI) di perairan Pesisir Barat provinsi Bengkulu. Metode yang digunakan yaitu wawancara dan pengolahan citra klorofil-a dan suhu permukaan laut yang diekstraksi melalui citra MODIS Aqua rata-rata bulanan selama 12 bulan. Hasil penelitian menyebutkan bahwa paramater tradisional dalam menentukan ZPPI baik oleh nelayan Bengkulu Selatan maupun Bengkulu Utara berdasarkan pada; a) bukit/gunung, suhu, arus, dan kecerahan air laut, timah pancing, karang/lumpur, tower dan pohon. Zona potensial penangkapan ikan paling banyak berada di perairan Tenggara, yakni kabupaten Bengkulu Utara dan kabupaten Muko-muko, serta di sisi Barat Laut terdapat di kabupaten Bengkulu Selatan. Sementara di bagian tengah, seperti kota Bengkulu dan Seluma hampir tidak memliliki zona penangkapan ikan dengan potensi hasil tangkap yang tinggi.
\end{abstract}

Kata kunci: suhu permukaan laut, klorofil-a, ZPPI

\begin{abstract}
The research aims to; (1) knowing the traditional parameters of the Bengkulu province community in determining fishing zones, (2) mapping the potential fishing zones (ZPPI) in the West Coast waters of Bengkulu province. The method used is interviewing and processing chlorophyll-a images and sea surface temperature extracted through MODIS Aqua images on average monthly for 12 months. The results of the study stated that traditional parameters in determining ZPPI by Bengkulu Selatan and Bengkulu Utara fishermen were based on; a) hills / mountains, temperature, currents, and brightness of sea water, lead fishing, coral / mud, towers and trees. The most potential fishing zones are in the waters of the Northwest, namely North Bengkulu and Muko-muko districts, and on the southeast side are in Bengkulu Selatan regency. While in the middle, such as Bengkulu city and Seluma have almost no fishing zones with high potential for fishing.
\end{abstract}

Keywords: sea surface temperature, chlorophyll-a, ZPPI

\section{PENDAHULUAN}

Provinsi Bengkulu terdiri dari 10 kabupaten/kota, tujuh di antaranya berhadapan langsung dengan laut. Artinya sub sektor perikanan memberikan pengaruh signifikan terhadap perekonomian provinsi ini. Potensi sub sektor perikanan di provinsi Bengkulu cukup besar, yakni mencapai 126.217 ton per tahun dengan luas zona ekonomi ekslusif (ZEE), $685.000 \mathrm{Km}^{2}$ [1].

Selain itu, penguatan komoditas agromaritim unggulan dan pengentasan kemiskinan merupakan salah satu program prioritas yang tertuang dalam RPJMD
Provinsi Bengkulu 2016 - 2021. Dalam jangka waktu 5-10 tahun ke depan, pemerintah daerah mengharapkan pendapatan asli daerah (PAD) sebesar 30 persen berasal dari sektor kelautan dan perikanan [2], [3].

Tampaknya harapan di atas sulit untuk dicapai, sebab sampai saat ini para nelayan masih menemukan hambatan berupa ketidakpastian tentang lokasi potensi penangkapan ikan (fishing ground). Sejauh ini para nelayan masih menggunakan cara-cara tradisional, berdasarkan pada kemampuan individu nelayan, atau yang diwarisi secara turun-temurun (insting). Akibatnya, nelayan tidak mampu mengantisipasi perubahan 
kondisi oseanografi dan cuaca yang berkaitan erat dengan daerah potensi penangkapan ikan yang berubah secara dinamis dari waktu ke waktu. Bahkan sering terjadi ekspansi penangkapan "nelayan besar" ke daerah penangkapan "nelayan kecil" sehingga berdampak pada persaingan yang kurang sehat antarnelayan [4], seperti konflik yang terjadi antarnelayan di Bengkulu sekitar Januari hingga Maret 2018. Jika situasi seperti ini terus berlangsung, maka pemanfaatan potensi sumberdaya perikanan laut menjadi kurang maksimal. Terbukti bahwa tingkat pemanfaatan potensi lestari perikanan tangkap provinsi Bengkulu hanya 24.168 ton per tahun, sementara potensi sebenarnya mencapai 126.217 ton per tahun [5], [1].

Berangkat dari masalah di atas, ilmu dan teknologi bagi nelayan sangat dibutuhkan kegiatan penangkapan ikan akan lebih efektif dan efisien jika area penangkapan ikan dapat diprediksi sebelumnya [6]. Oleh karena itu, diperlukan penelitian tentang informasi secara spasial dan temporal lokasi yang prospektif untuk kegiatan penangkapan ikan. Informasi mengenai variabilitas suhu permukaan laut (SPL) dan sebaran klorofil-a dalam bidang perikanan memiliki peranan penting sebagai sarana untuk penentuan lokasi Zona Potensial Penangkapan Ikan (ZPPI) atau fishing ground. Saat ini telah terdapat teknologi yang dikenal dengan satelit penginderaan jauh yang memiliki kemampuan untuk mendeteksi beberapa parameter oseanografi khususnya suhu permukaan laut dan klorofil-a yang berkaitan erat dengan kehidupan ikan khususnya ikan pelagis, seperti citra satelit MODIS (sensor Terra maupun Aqua) [4], [7].

Berdasarkan permasalahan di atas, penelitian ini dimaksudkan untuk ; (1) mengetahui parameter tradisional tentang zona potensial penangkapan ikan, (2) memetakan zona potensial penangkapan ikan di laut provinsi Bengkulu.

\section{METODE PENELITIAN}

\section{Lokasi Penelitian}

Wilayah dalam penelitian ini mencakup seluruh laut provinsi Bengkulu yang membentang antara $2^{\circ} 16^{\prime}-5^{\circ} 31^{\prime}$ LS dan $101^{\circ} 01^{\prime}-103^{\circ} 41^{\prime}$ BT memanjang dari Tenggara ke Barat Laut. Kecuali pulau Enggano, Mega, Tikus dan pulau-pulau kecil yang ada di sekitarnya.

\section{Populasi dan Sampel}

Populasi dalam penelitian ini adalah perairan (laut) Bengkulu dengan batas kedalaman 200 meter. Hal ini dikarenakan fokus penelitian pada potensi ikan Pelagis saja, yang hidup pada batas kedalaman tersebut. Sedangkan untuk sampel lokasi wawancara; bagian Tenggara diwakili oleh nelayan Kelurahan Lubuk Tandjung Kec. Air Napal Kab. Bengkulu Utara dan bagian Barat Laut di wakili oleh nelayan Kel. Pasar Bawah Kec. Pasar Manna dan Kel. Pasar Pino Kec. Pino Raya Kabupaten Bengkulu Selatan.

\section{Teknik Pengolahan dan Analisis Data}

1) Download data MODIS

Citra satelit suhu permukaan laut dan klorofil-a diunduh dari satelit MODIS Aqua Level 3 dengan resolusi spasial 4 $\mathrm{Km}$ dan resolusi temporal bulanan (monthly) pada alamat situs; https://oceancolor.gsfc.nasa.gov/13/. Pada level ini, data citra telah terkoreksi radiometrik dan geometrik, serta algortitma telah diterapkan secara otomatis [8]. Kemudian periode bulanan dipilih karena citra harian banyak yang tertutup awan (tidak dapat digunakan) [9]. Sehingga berdampak pada banyaknya digital number yang kosong.

2) Pemotongan citra

Cropping atau pemotongan citra dilakukan dengan menggunakan SeaDAS 7.5 (crop > geo coordinates : north : - 2, west : 94 , south : -8 , east : 105).

3) Ekstraksi nilai piksel $(x, y)$

Nilai piksel SPL dan klorofil-a diekstraksi menggunakan software SeaDAS 7.5 (vectors > geometry > eksport mask pixels > write to file).

4) Analisis IDW \& counturing Interpolasi menggunakan IDW (Invers Distance Weighted) yaitu metode deterministik sederhana dengan cara 
mempertimbangkan titik disekitarnya, dengan asumsi nilai interpolasi akan lebih mirip pada data sampel yang dekat daripada yang lebih jauh [10]. Tahapan ini dilakukan menggunakan ArcGIS 10.2 (spatial analyst tools > interpolation > IDW). Langkah berikutnya yakni, mengubah hasil interpolasi tersebut ke dalam kontur (spatial analyst tools > surface $>$ contour).

5) Overlaying \& plotting

Titik ZPPI ditentukan dengan cara melihat kontur sebaran SPL dan klorofila yang saling berpotongan satu sama lain [11]. Nilai konsentrasi klorofil-a yang digunakan untuk keperluan plotting dimulai dari $0,2 \mathrm{mg} / \mathrm{m}^{3}$ dan SPL $25{ }^{\circ} \mathrm{C}-$ $32{ }^{\circ} \mathrm{C}$ umumnya dengan nilai kisaran tersebut merupakan ekosistem yang baik untuk ikan dapat hidup [7]. Caranya adalah dengan meng - overlay kedua kontur tersebut. Selanjutnya identifikasi titik yang saling berpotongan ke dalam file baru (.Shp). Lakukan plotting pada titik tersebut, setelah itu esktrak koordinat $\mathrm{X}$ dan $\mathrm{Y}$ (data management tools $>$ features $>$ add $\mathrm{xy}$ coordinates). Koordinat akan terisi secara otomatis di tabel atribut.

\section{HASIL DAN PEMBAHASAN}

\section{Parameter Tradisional}

Parameter tradisional antara nelayan bagian Barat Laut yang diwakili oleh Kab. Bengkulu Utara dan nelayan bagian Tenggara yang diwakili oleh Kab. Bengkulu Selatan menunjukkan adanya persamaan dan perbedaan dalam menentukan zona potensial penangkapan ikan. Berikut ringkasannya.

Tabel 2. 1. Parameter Tradisional ZPPI

\begin{tabular}{ll}
\hline Lokasi Nelayan & Parameter \\
\hline Kab. Bengkulu & $\begin{array}{l}\text { Bukit/gunung, suhu, arus, } \\
\text { kecerahan air laut dan timah } \\
\text { pancing/gantung. }\end{array}$ \\
Kab. Bengkulu Utara & $\begin{array}{l}\text { Bukit/gunung, suhu, arus, } \\
\text { kecerahan air laut, tower, } \\
\text { karang/lumpur dan pohon. }\end{array}$ \\
\hline
\end{tabular}

Sumber : Pengolahan data, 2019
Bagi nelayan di Bengkulu Selatan, kenampakan fisik yang menjadi parameter dalam menentukan zona tangkap ikan yang pertama adalah bukit Sebilau. Bukit tersebut mereka gunakan sebagai penanda jarak sekaligus titik acuan dalam menentukan zona tangkap.

Paramater lainnya adalah suhu. Ketika suhu hangat maka kelimpahan ikan di laut akan lebih banyak. Arus dan suhu biasanya digunakan secara bersamaan dan dideteksi menggunakan tangan, jika arus ke Tenggara maka mereka mencari ikan ke arah Barat Laut, begitu sebaliknya.

Warna atau tingkat kecerahan air laut juga menjadi bagian penting, terutama ketika cuaca sedang cerah. Jika air laut berwarna biru, pertanda zona tersebut sedikit ikannya, namun apabila berwarna kehijauan maka ikan cukup melimpah.

Laut di Bengkulu Selatan relatif dalam, sehingga nelayan harus menggunakan senar dan timah pancing untuk memberi tanda zona tangkap (plotting), jika teridentifikasi keras maka lokasi tersebut adalah karang, jika teridentifikasi lembut dan tidak dirasakan ada benturan timah maka lokasi tersebut adalah lumpur. Dalam hal ini nelayan menggabungkan dengan parameter bukit/gunung sebagai titik acuan bahkan GPS sebagai tracker jika kondisi cuaca sedang buruk/berkabut. Titik yang didapat melalui timah pancing tadi digunakan kembali keesokan harinya sedangkan bukit/gunung sebagai tetap sebagai acuan.

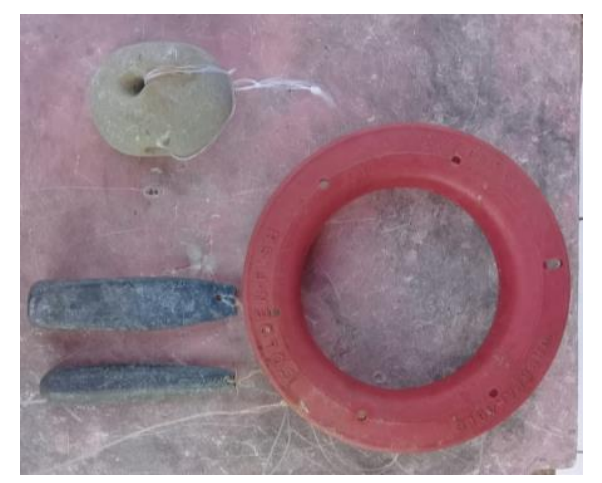

Gambar 1. Timah pancing sebagai salah satu alat "plotting" tradisional yang digunakan oleh nelayan Ps. Bawah Kab. Bengkulu Selatan. Sumber : Dokumentsi lapang th. 2019 
Parameter fisik berupa bukit/gunung, suhu, arus, dan kecerahan air laut digunakan juga oleh para nelayan di Bengkulu Utara, baik itu cara menggunakan maupun tujuannya. Perbedaan terdapat pada nama bukit/gunung. Nelayan Air Napal menggunakan gunung Bungkuk dan bukit Barisan yang berada di sisi Barat sebagai acuan di darat.

Perbedaan lainnya terdapat pada penggunaan tower (Telkom) dan pohon. Keduanya memiliki perbedaan tinggi dengan daerah sekitarnya sehingga masih bisa terlihat dari kejauhan dan menjadi titik acuan. Selain itu, nelayan di Bengkulu Utara tidak menggunakan timah pancing untuk mendeteksi keberadaan lumpur atau karang, karena laut relatif dangkal sehingga masih dapat terlihat secara kasat mata terutama saat cuaca cerah.

\section{Suhu Permukaan Laut dan Klorofil-a}

Berdasarkan hasil pengolahan citra Satelit MODIS Sensor Aqua pada Bulan Juni 2018 sampai dengan Mei 2019, diketahui bahwa suhu permukaan laut di Bengkulu berkisar antara $27{ }^{\circ} \mathrm{C}$ hingga $30{ }^{\circ} \mathrm{C}$. Suhu terendah $\left(27^{\circ} \mathrm{C}\right)$ terjadi pada bulan September dan Oktober, sedangkan suhu tertinggi $\left(30^{\circ} \mathrm{C}\right)$ terjadi pada bulan Januari hingga Juni. Secara umum, perairan tropis memang memiliki suhu yang relatif tinggi dengan rata-rata bulanan SPL berkisar antara $26-31{ }^{\circ} \mathrm{C},[12]$.

Konsentrasi klorofil-a tertinggi terdapat pada bulan Januari dan Juni, sedangkan konsentrasi terendah terdapat pada bulan Februari. Jika dilihat dari data yang ada, ratarata kandungan klorofil-a di laut provinsi Bengkulu lebih dari $0.2 \mathrm{mg} / \mathrm{m}^{3}$. Intensitas penyinaran matahari dapat menjadi salah satu penyebab tingginya konsentrasi klorofil-a [13]. Hal ini dapat dilihat pada Gambar 3. 2. dimana setiap terjadi peningkatan suhu maka terjadi pula peningkatan konsentrasi klorofil-a atau sebaliknya (fluktuatif).

Keberadaan konsentrasi klorofil-a di atas $0.2 \mathrm{mg} / \mathrm{m}^{3}$ mengindikasikan keberadaan plankton yang cukup untuk menjaga kelangsungan hidup ikan-ikan ekonomis penting [14]. Namun sayangnya, sebaran klorofil-a tersebut tidak merata di setiap kabupaten/kota-nya.

Keberadaan klorofil-a di provinsi Bengkulu paling banyak terdapat di laut kab. Bengkulu utara, kemudian diikuti laut kab. Bengkulu Selatan dan Muko-muko.

Klorofil-a dan suhu permukaan laut (SPL) juga memiliki hubungan dalam meningkatkan hasil tangkap ikan terutama jenis pelagis. Jika SPL rendah, dan konsentrasi klorofil-a tinggi maka hasil tangkapan akan meningkat. Sebaliknya, jika SPL tinggi dan konsentrasi klorofil rendah, maka hasil tangkapan berkurang [5], [15],

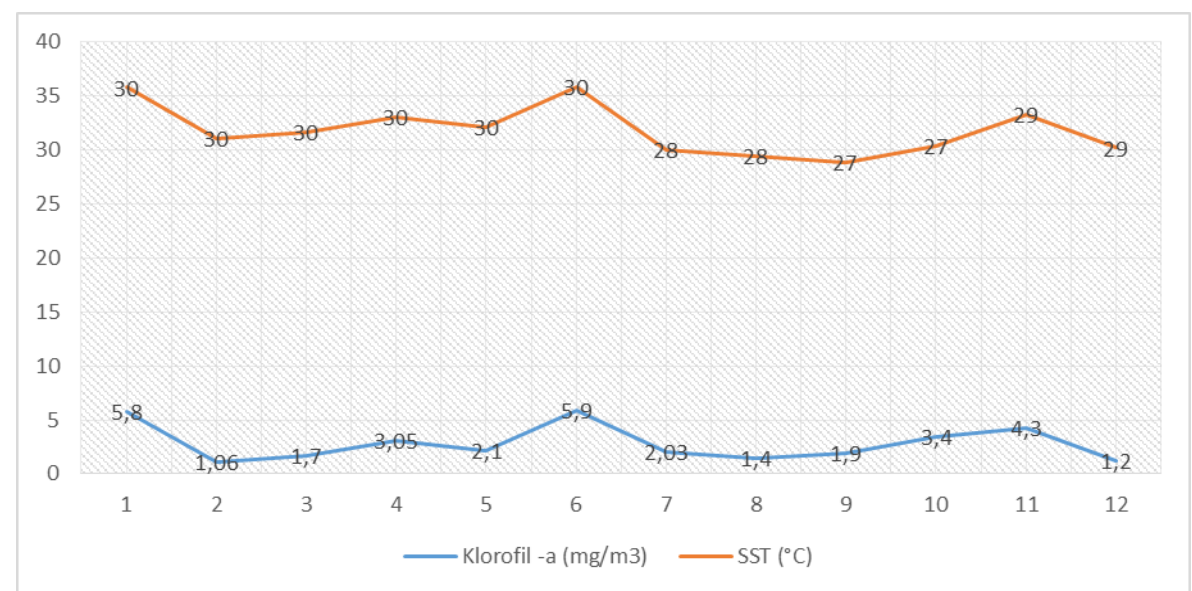

Gambar 2. Fluktuasi Rata-rata Klorofil-a dan Suhu Permukaan Laut Sumber : Pengolahan data tahun 2019 

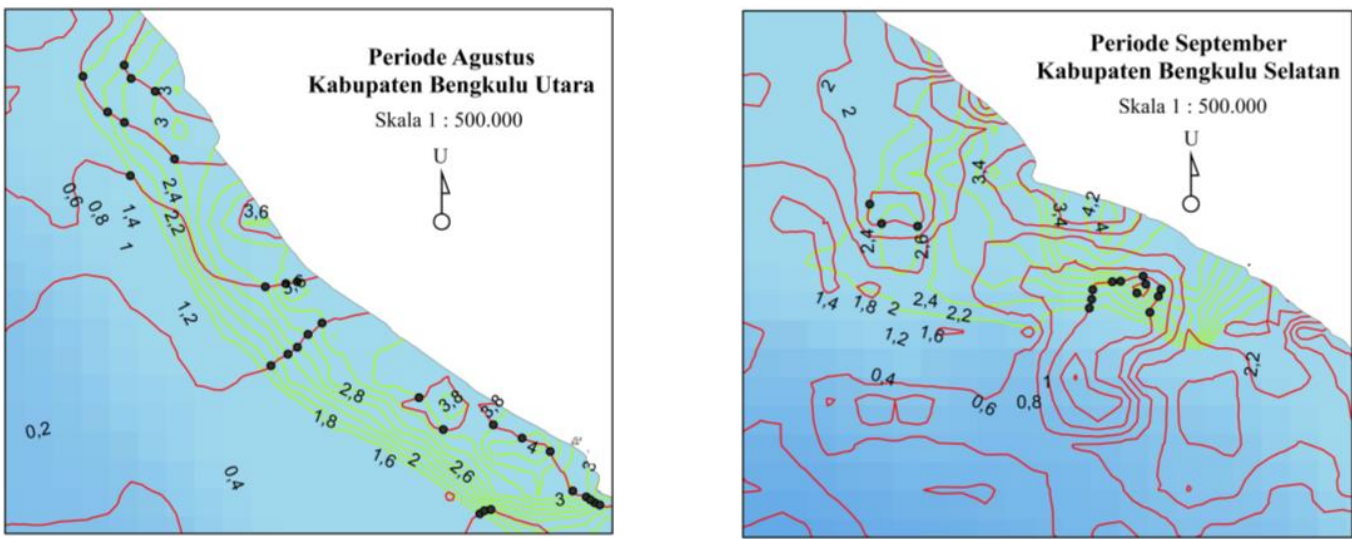

Gambar 3. Contoh hasil overlay antara suhu permukaan laut dengan klorofil-a Sumber : Pengolahan data tahun 2019

Berdasarkan gambar 3. 3 di atas, dapat dikatakan bahwa kelimpahan ikan di kabupaten Bengkulu utara pada bulan Agustus tersebar secara merata. Kandungan klorofil-a paling tinggi pada bulan tersebut mencapai $7,6 \mathrm{mg} / \mathrm{m}^{3}$. Sementara, kelimpahan ikan di kabupaten Bengkulu Selatan pada bulan September cenderung mengelompok atau bergerombol. Kandungan klorofil paling tinggi mencapai $7,6 \mathrm{mg} / \mathrm{m}^{3}$ dengan suhu berkisar antara $27-30{ }^{\circ} \mathrm{C}$.

\section{Zona Potensial Penangkapan Ikan}

Zona potensial penangkapan ikan di kabupaten Bengkulu Utara hampir meliputi setiap bulan, kecuali pada bulan Oktober dan November. Pada dua bulan tersebut minim potensi penangkapan, zona tangkap lebih banyak di laut Muko-muko dan terus bergerak ke bulan berikutnya hingga mendekati perbatasan kabupaten Pesisir Selatan Provinsi Sumatera Barat. Diukur dari garis pantai terdekat, zona penangkapan ikan di wilayah ini berkisar antara 4,2 - 16 Mil laut. Pola jalur penangkapan lebih ke arah Tenggara, yakni pantai Tandjung Aur, Kedurang dan Padang Guci.

Sementara itu, zona potensial penangkapan ikan di kabupaten Bengkulu Selatan tidak sebanyak di kab. Bengkulu Utara. Potensi penangkapan ikan di wilayah ini terdapat pada bulan Januari s/d Juli dan September dengan jarak tangkap hingga 10,1 Mil laut. Berikut disajikan peta zona potensial penangkapan ikan (ZPPi) provinsi Bengkulu dari bulan Juni 2018 sampai dengan bulan Mei 2019 (12 bulan). 

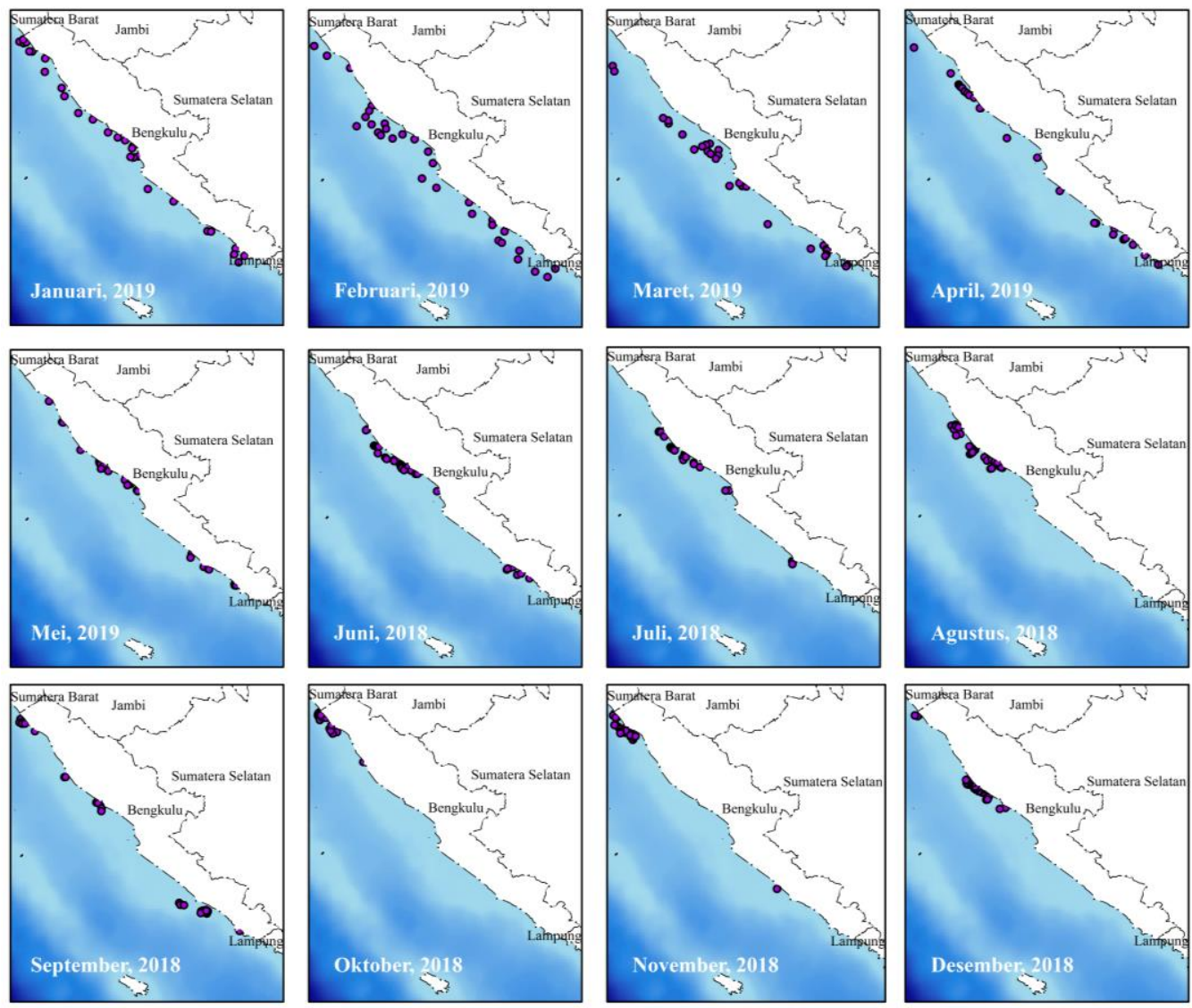

Gambar 4. Zona Potensial Penangkapan Ikan Provinsi Bengkulu, Skala 1 : 6.000 .000

Sumber : Pengolahan data tahun 2019

\section{KESIMPULAN}

Klorofil-a rata-rata bulanan di laut provinsi Bengkulu berkisar antara 1,06 hingga $5,9 \mathrm{mg} / \mathrm{m}^{3}$. Sedangkan rata-rata ${ }_{\text {maks }}$ suhu permukaan lautnya sebesar $30{ }^{\circ} \mathrm{C}$. Hal ini menunjukkan bahwa perairan tersebut cukup subur. Namun sayang, sebarannya tidak merata sehingga hanya wilayah tertentu saja yang cukup potensial dilakukan penangkapan ikan terutama pelagis.

Kebiasaan nelayan Bengkulu dalam menentukan zona tangkap ikan mereka peroleh secara turun-temurun (insting) dari nenek moyang mereka dan sebagian belajar dengan rekan satu profesi.

Para nelayan di Bengkulu Selatan dan Bengkulu Utara pada umumnya masih menggunakan parameter tradisional berupa; bukit/gunung, suhu, arus, dan kecerahan air laut. Perbedaan keduanya dalam menentukan
ZPPI terdapat pada; timah pancing, karang/lumpur, tower dan pohon. Parameter fisik/alam di darat mereka gunakan sebagai titik acuan sedangkan paramater di laut mereka gunakan sebagai penanda atau ploting.

Berdasarkan pengolahan citra suhu permukaan laut dan klorofil-a yang diekstraksi dari citra satelit MODIS sensor Aqua rata-rata bulanan disebutkan bahwa zona potensial penangkapan ikan paling banyak berada di perairan Barat Laut, yakni kabupaten Bengkulu Utara dan kabupaten Muko-muko, serta di sisi Tenggara terdapat di kabupaten Bengkulu Selatan. Sementara di bagian tengah, seperti kota Bengkulu dan Seluma hampir tidak memliliki zona penangkapan ikan dengan potensi hasil tangkap yang tinggi. 


\section{UCAPAN TERIMA KASIH}

Ucapan terima kasih disampaikan kepada Direktorat Jenderal Penguatan Riset dan Pengembangan (c.q Direktorat Riset dan Pengabdian Masyarakat - DRPM Ristekdikti), Lembaga Layanan Pendidikan Tinggi Wilayah II (L2DIKTI - II), serta Lembaga Penelitian dan Pengabdian kepada Masyarakat (LPPM) Universitas Dehasen Bengkulu.

\section{DAFTAR PUSTAKA}

[1] Awi. Potensi Perikanan Tangkap Bengkulu Belum Digarap. Antara Bengkulu [serial online] Maret 2012 [Sitasi 30 September 2018] di : https://bengkulu.antaranews.com/berita/ 2043/potensi-perikanan-tangkapbengkulu-belum-digarap

[2] Bapelitbang Provinsi Bengkulu. Rencana Aksi Daerah Kemaritiman Provinsi Bengkulu Tahun 2017. Bengkulu; 2017

[3] Nusir, S. R., Moninta, D. R., Dahuri, R., Kusumastanto, T., Budiharjo, S. Analisis Strategi Pengelolaan dan Pengembangan Sumberdaya Perikanan Provinsi Bengkulu. Agrimansion. 2008; 9 (1): $1-14$.

[4] Hasyim, B. Pengembangan dan Penerapan Informasi Spasial dan Temporal Zona Potensi Penangkapan Ikan Berdasarkan Data Penginderaan Jauh. Bogor : Maxymum; 2017

[5] Insanu, R. K. Pemetaan Zona Tangkapan Ikan (Fishing Ground) Menggunakan Citra Satelit Terra Modis dan Parameter Oseanografi Di Perairan Delta Mahakam. GEOID. 2017; 12 (2): $111-119$.

[6] Usman, Sari, T. E. Y. Syaifuddin, Audina. The relationship between concentration of Clorophyll-a With Skipjack (Katsuwonus pelamis, Linnaeus 1758) production at West
Sumatera Waters, Indonesia. IOP Conference Series: Earth and Environmental Science. 2017; 54 (012072): $2-5$.

[7] Munthe, M. G. , Putra, R. D., Jaya, Y. V. Pemetaan Zona Potensial Penangkapan Ikan Berdasarkan Citra Satelit Aqua/Terra Modis Di Perairan Selatan Laut Jawa. Dinamika Maritim. 2018; 7 (1): 39 - 42.

[8] Anggreyni. D., A., R. Studi Perubahan Suhu Permukaan Laut (SPL) Menggunakan Satelit Aqua Modis. 2011. Diperoleh dari situs: http://digilib.its.ac.id/public/ITSUndergraduate-17574-Presentation.pdf

[9] Bukhari, Adi, W., Kurniawan. Pendugaan Daerah Penangkapan Ikan Tenggiri Berdasarkan Distribusi Suhu Permukaan Laut Dan Klorofil-A Di Perairan Bangka. Jurnal Perikanan Tangkap. 2017. 1 (3): 1 - 22.

[10] Pramono, G. H. Akurasi Metode IDW dan Kriging Untuk Interpolasi Sebaran Sedimen Tersuspensi di Maros, Sulawesi Selatan. Forum Geografi. 2008; 22 (1): 145-158

[11] Semedi, B., Hadiyanto, A.L. Forecasting the Fishing Ground of SmallPelagic Fishes in Makassar Strait Using Moderate Resolution Image Spectroradiometer Satellite Images. Journal of Applied Environmental and Biological Sciences. 2013; 3 (2): 29-34.

[12] Gaol, J.L., Arhatin, R.E., Ling, M.M. Pemetaan Suhu Permukaan Laut dari satelit di perairan Indonesia untuk mendukung "One Map Policy", Prosiding Seminar Nasional Penginderaan Jauh. Bogor. 2014; 433442. 
[13] Cahya, C. N., Setyohadi, D., \& Surinati, D. Pengaruh Faktor Oseanografi Terhadap Distribusi Ikan. Oseana. 2016; 16 (4): 1 - 14.

[14] Suhartono., Haruna dan Pailin, J. B., Identifikasi Daerah Penangkapan Ikan Kembung (Rastreliger, spp) Di Perairan Kabupaten Pangkep. Jurnal Amanisal. 2013; 2 (2): $55-65$.
[15] Adnan. Analisis Suhu Permukaan Laut Dan Klorofil-A Data Inderaja Hubungannya Dengan Hasil Tangkapan Ikan Tongkol (Euthynnus affinis) Di Perairan Kalimantan Timur. Jurnal Amanisal. 2010; 1 (1): 1 - 12. 